all my shots which hit outside them we sha'n't count." If we eliminate those who teach for nothing at all, why not disregard those who get less than a specified sum, say $\$ 1,500$ ? It would make a still more favorable showing for the average. The writer must confess inability to follow his critic's logic in this.

The writer has no prejudice against Temple College. It may be doing the worthy work your correspondent vouches for. The writer's passing curiosity was aroused by the fact that it appears to provide for the needs of 2,343 students, and a teaching staff of 198 , out of an entire annual expenditure of $\$ 72,895$, and so he gave voice to it. When all the facts are known, it is quite possible that this institution may be found to have sounder standards than many another guilty of extravagant and ostentatious expenditures. The more light we can get on these points the better.

After all, your correspondent and the writer don't disagree on the main point at issue, namely, that honest and reliable statistics are vitally necessary. Only, the writer was laboring under the impression that, so far as concerned data not previously common property, he was supplying to a slight extent just that kind of accurate material. Assuredly he has made effort enough to have it so; his conscience acquits him on that score. And it will take rather more convincing proof than that offered by this correspondent to shake his faith in its value. GuIdo H. MarX

\section{WARNING TO ZOOLOGISTS AND OTHERS}

ZooLogists and geologists generally are warned that a clever swindler is making a canvass of the zoologists of New York, seeking money under false pretenses. He operates by claiming to be the "nephew" of some wellknown scientist who is a personal friend of the intended victim; and the skill and thoroughness with which he prepares each case is fairly amazing. He knows thoroughly the scientific men of Washington, and especially those of the National Museum and the Cosmos Club.

In person he is tall (about 5 feet 10 inches), neatly and cleanly dressed, smoothly shaven and weighs about 170 pounds. $\mathrm{He}$ can instantly be recognized by his broad, flat face, small shifty eyes set widely apart, wide mouth, flabby lips and a long conspicuous row of upper teeth, all of them very evenly discolored by tobacco. When attempting to work his game, he laughs nervously fully half the time that he is talking.

If any intended victim of this man will hand him over to a policeman, I will very willingly arrange for witnesses to appear against him, for the purpose of landing him where he belongs. W. T. Hornaday

New York Zoological Park, July 8, 1909

WE have also received the following statement from the secretary of the Smithsonian Institution: A man familiar with scientific men of Washington and New York, claiming to be a nephew of the secretary of the Smithsonian Institution, has recently been securing money as a personal loan from friends of the secretary upon false pretenses. The secretary has no such nephew; the man is a swindler. He may be described as follows: Tall and large, weight about 165 pounds; Eskimo-like face, smoothly shaven; mouth, wide; lips, flabby; long conspicuous row of upper teeth evenly discolored by tobacco; age about 35 ; carries head inclined to the right; laughs almost constantly while talking.

\section{SCIENTIFIC BOOKS}

Ethics. By John Dewey and James H. TuFrs. New York, Henry Holt and Co. Pp. xiii +618 .

Characteristic phases of ethical study during the last twenty-five years are the interest shown in the history of morality and the attention given to social, economic and political questions. The works of Letourneau, Sutherland, Westermarck and Hobhouse are able examples of the fruitfulness of the genetic method in ethical science, while the books of Wundt, Paulsen and Bergemann combine with the historical and theoretical treatment a discussion of the larger social problems that are agitating the civilized peoples of to-day. 